\title{
PERUBAHAN IKLIM DAN PERDAGANGAN KARBON DARI PENURUNAN EMISI GAS RUMAH KACA (GRK)
}

\author{
Wardoyo \\ Universitas Muhammadiyah Tangerang \\ wwardoyo@hotmail.com
}

\section{Keyword \\ Carbon market, Climate change, GHG emissions, Trading in islam, REDD.}

\begin{abstract}
Green house gases (GHG) in the atmosfer increase rapidly as a result of human activities such as the use of fossil energy for industry, power, and transportation, as well as the change of land uses for settlement, crop estates, buildings and others. Increase of GHG on air will rise temperature up, and change climate on earth. Scientific evidence indicated that climate change is a serious threat and needs urgent action. An increase in temperature for 20 celcius may cause a severe disaster such as flooding along shore lines and small islands, extinction of $15 \%-40 \%$ species, and decrease of $20 \%$ agricultural products. GHG emissions can be reduced in several ways among other things are by decreasing demand on goods and services that causes intensive emissions, and avoiding activities that change land uses i.e., deforestation, estate crop development and mining. Markets for carbon trading are available in Tokyo, New York, Chicago, and this market encourages efficient GHG emission reduction. REDD is another scheme of carbon trading. In this scheme carbon emissions reduction from the forests will receive incentive/compensation (in financial value). However, the scheme is still in a process of development in global negotiation. This paper highlighted and described background on climate change, efforts to

reduce GHG emissions, REDD scheme and problems in its implementation.
\end{abstract}

\section{PENDAHULUAN}

\section{Latar Belakang Masalah}

Perubahan iklim memberikan tantangan tersendiri di bidang ekonomi. Analisis ekonomi terhadap perubahan iklim mencakup masalah global, menyangkut horison waktu jangka panjang, dan mengandung risiko dan ketidakpastian (Stern, 2006; Wilkinson, 2005). Masalah perubahan iklim melibatkan pemerintah, organisasi nonpemerintah, dan pengusaha serta terkait pula dengan negosiasi internasional. Oleh karena itu, pemecahan permasalahan tersebut memerlukan analisis ekonomi yang kompleks.

Perubahan iklim telah menjadi pembicaraan rutin tahunan dalam forum global 'Conference of Parties' (COP). Tahun lalu merupakan pertemuan ke 18 yang berlangsung di Doha - Qatar dari tanggal 26 November 2012 sampai dengan 8 Desember 2012 yang dihadiri delegasi para pihak dari negara maju dan negara berkembang. Pada pertemuan ini lebih di fokuskan pada negosiasi dan sebagaimana pertemuan-pertemuan sebelumnya, tidak ada kesepakatan untuk melakukan kegiatan dan tindakan dalam mengatasi permasalahan akibat perubahan iklim.

Perubahan iklim merupakan ancaman serius bagi kehidupan di dunia dan perlu tindakan segera. Sebagaimana diungkapkan oleh Stern (2006), iklim bumi berubah cepat utamanya disebabkan oleh kenaikan gas rumah kaca (GRK) di udara sebagai akibat kegiatan manusia diantaranya penggunaan energi fosil (24\%), alih fungsi dan penggunaan lahan (I8\%), 
industri (I4\%), transportasi (I4\%), pertanian (I4\%), pemukiman/bangunan (8\%) (Gambar I).

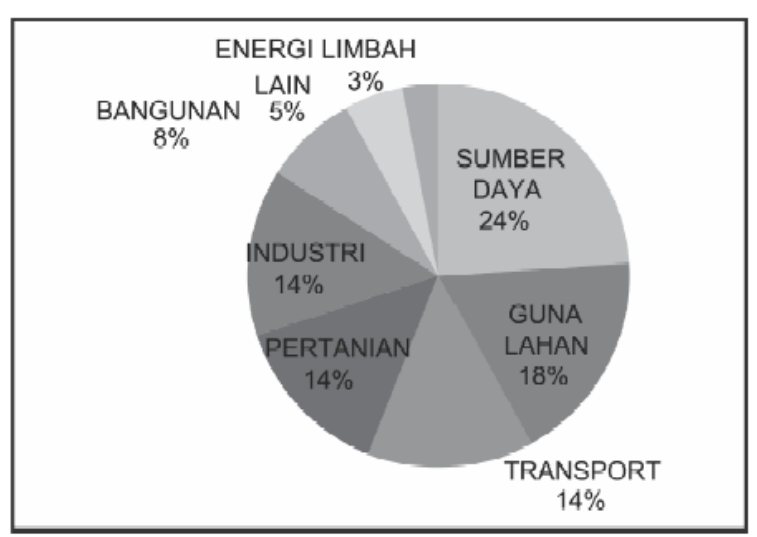

\section{Gambar I: Sumber Emisi GRK dalam persen (WRI, 2006)}

Gas rumah kaca (GRK) terdiri dari gas CO2 (karbon dioksida) sebagai komponen utama, dan gas lainnya: Non-CO2 (non-karbon dioksida) yaitu gas methan (CO4), nitrogen (N2O) dan lainnya. Kenaikan GRK mempunyai efek meningkatnya panas di muka bumi karena meningkatnya jumlah radiasi infra-merah yang terperangkap di atmosfir, biasa disebut dengan efek gas rumah kaca (GRK) atau green house gas (GHG) effect.

Dampak perubahan iklim Pada kurun waktu antara tahun 2030 - 2060 yang akan datang, tingkat GRK di udara diperkirakan akan meningkat 3 (tiga) kali dari tingkat GRK pada saat pra-revolusi industri. Sejak pra-revolusi industri (1750) konsentrasi CO2 (karbon dioksida) telah bertambah sepertiga, yaitu dari 280 ppm (parts per million) menjadi 380 ppm saat ini (20II) sebagai akibat dari meningkatnya pembakaran bahan energi fosil, terjadinya penggundulan hutan (deforestasi) dan perubahan penggunaan lahan (land cover \& land use changes). Konsentrasi $\mathrm{CO} 2$ terus meningkat diikuti dengan peningkatan konsentrasi GRK lainnya terutama gas methan (CO4) dan nitrogen (N2O).

Trend kenaikan konsentrasi GRK global akan mengakibatkan naiknya temperatur 20 5o Celcius dalam 50 tahun kedepan, dan temperatur akan terus meningkat jika emisi GRK tidak berkurang. Kenaikan temperatur akan mempunyai akibat serius terhadap kehidupan di muka bumi. Es di kutub akancepat mencair yang akan meningkatkan permukaan air laut, sehingga ratusan juta orang di wilayah pantai (Bangladesh, Vietnam, Thailand, Indonesia
dII.), pulau-pulau kecil, dan kota-kota besar di tepi pantai (Tokyo, New York, Jakarta dII.) akan terkena banjir setiap tahun. Dengan kenaikan temperatur 20 Celcius, 15\% - $40 \%$ species yang ada berpotensi punah. Jika tingkat $\mathrm{CO} 2$ meningkat, maka keasaman laut akan meningkat yang berpengaruh terhadap ekosistem laut dan menurunnya stok ikan.

Disamping itu, meningkatnya perubahan penggunaan lahan sebagai salah satu sumber emisi GRK, akan memperparah penurunan hasil pertanian. Hasil pertanian akan menurun sekitar $20 \%$ karena beberapa jenis tanaman akan mati akibat kenaikan temperatur bumi tersebut. Turunnya hasil pertanian akan mengakibatkan ratusan juta orang kekurangan makanan, dan kematian penduduk akan meningkat karena malnutrisi dan kepanasan. Misalnya di Indonesia, lahan pangan yang beralih fungsi menjadi lahan non-pangan (industri/pabrik, pemukiman/real estate) diperkirakan 100 ribu ha/tahun; dilain pihak jumlah penduduk akan terus meningkat, pada tahun 2050 penduduk Indonesia diperkirakan akan meningkat menjadi 500 juta orang.

Oleh karena itu masalah pangan akan semakin rawan dimasa yang akan datang. Upaya menurunkan emisi GRK Terkait penurunan emisi GRK, Indonesia telah berkomitmen menurunkan emisi GRK pada tahun 2020 dengan upaya biasa (business as usual) sebesar $26 \%$ dengan dana sendiri atau $41 \%$ bila ada tambahan dana bantuan luar negeri. Emisi GRK dapat diturunkan dengan 4 (empat) cara, yaitu: (i) mengurangi permintaan barang \& jasa yang proses produksinya berakibat terjadinya emisi secara intensif, (ii) meningkatkan efisiensi yg dapat menghemat dana dan mengurangi emisi GRK, (iii) menghindari kegiatan yang mengakibatkan emisi non-energi/alih fungsi lahan, misal menghindari terjadinya penggundulan hutan (deforestasi), dan (iv) berpindah ke teknologi rendah emisi GRK terutama untuk tenaga listrik, dan transportasi (Stern, 2006). Cara dan teknologi yang dikemukakan tersebut perlu dikombinasikan, satu teknologi tidak mungkin dapat menurunkan emisi karena masing-masing teknologi memiliki keterbatasan. Terjadinya emisi GRK melibatkan banyaknya aktivitas dan sektor: kehutanan, 
pertanian, perkebunan, energi, pertambangan, pemukiman dll. Sektor energi merupakan sektor yang potensial dapat menurunkan emisi GRK secara signifikan apabila penggunaan energi dilakukan secara efisien. Demikian juga pengurangan emisi di sektor non-energi akan memberikan kontribusi cukup penting karena emisi nonenergi menyumbang sepertiga dari total emisi, dan biaya penurunan emisi dari sektor non-energi lebih murah dari sektor energi dan lainnya. Kegiatan yang menghindarkan terjadinya penggundulan hutan/deforestasi diperkirakan memerlukan biaya lebih murah dibanding dengan biaya mitigasi dengan cara lainnya, asalkan dibuat kebijakan yang tepat, dan diterapkan oleh institusi yang kredibel dan penuh tanggung jawab. Perdagangan Karbon Penurunan emisi karbon dapat diperdagangkan atau diperjualbelikandi pasar karbon (carbon market) berupa karbon kredit (carbon credit). Kredit karbon merupakan hak atas emisi GRK yang dapat dimiliki oleh suatu organisasi diantaranya berupa CER (Certified Emission Reduction), ERU (Emission Reduction Units), AAU (Assigned Amount Units), dan EUA (European Union allowances). Pasar karbon adalah suatu tempat dimana penjual dan pembeli melakukan transaksi jual-beli kredit karbon (telah ada di Tokyo, New York, Chicago). Mekanisme dan sistem yang berjalan di pasar karbon hampir sama dengan pasar saham. Pasar karbon bekerja berbasiskan pasar, dan pasar tersebut mendukung penurunan GRK secara efisien. Penawaran dan permintaan terhadap permintaan (demand) karbon kredit dalam periode komitmen pertama Kyoto Protocol (2008 - 2012) sebesar I.245MtCO2e; sedangkan jumlah penawaran (supply) sebesar 3.025MtCO2e (Gambar 2).

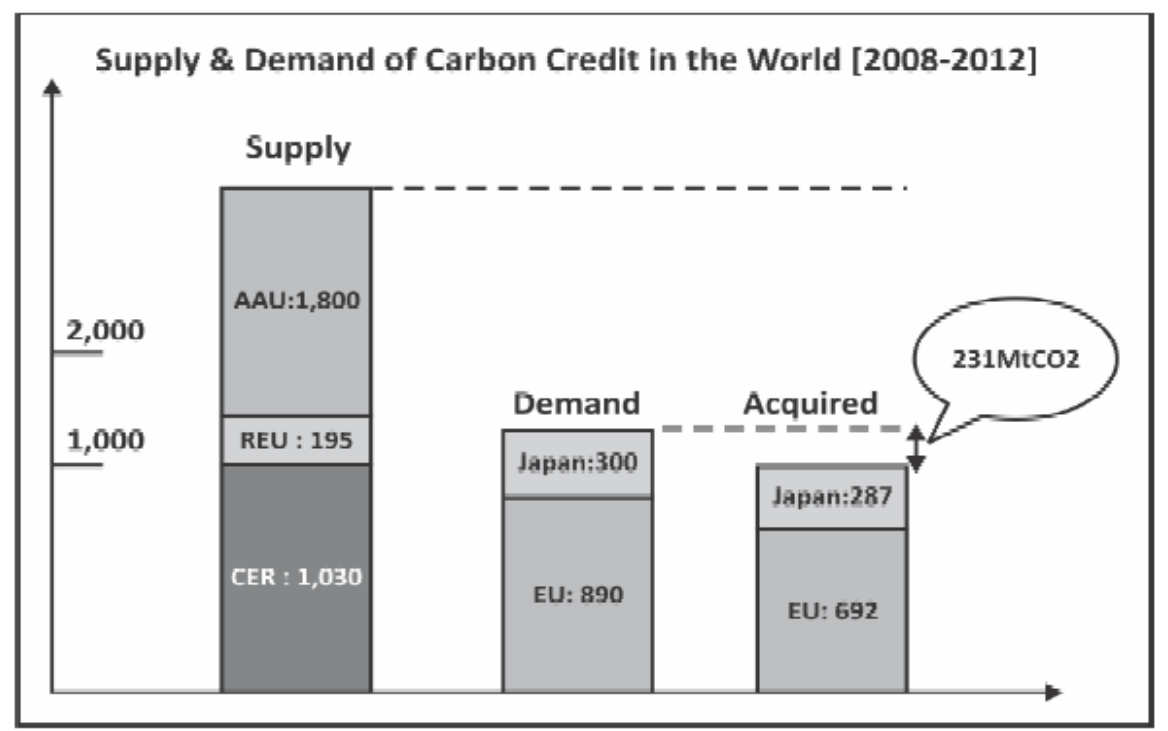

\section{Gambar 2. Penawaran dan permintaan karbon kredit di dunia tahun 2008-20I2. (Sumber: Climate Change Secretariate of Srilangka, 20I2)}

Penurunan Emisi GRK dengan skema REDD dan permasalahannya Dengan pandangan bahwa biaya penurunan emisi GRK lebih murah dengan menghindari terjadinya deforestasi dari pada biaya untuk melakukan penurunan emisi di sektor lain, investasi di sektor kehutanan menjadi menarik perhatian banyak pihak karena penurunan emisi dari deforestasi dan degradasi hutan akan mendapat insentif/kompensasi. Hal ini yang mendasari munculnya konsep penurunan emisi GRK dengan skema pengurangan emisi akibat deforestasi dan degradasi hutan (Reducing Emission from Deforestation and forest Degradation) yang dikenal dengan singkatan REDD. Dengan demikian, REDD adalah suatu mekanisme global untuk memberikan insentif kepada negara berkembang dalam melindungi dan mengelola sumber daya hutannya dengan baik, sehingga memberikan kontribusi terhadap pengurangan dan pencegahan dampak dari perubahan iklim (Satgas REDD+, 2012). Karbon yang tersimpan 
dalam ekosistem hutan diukur/dihitung dan dinilai secara finansial, dan negara maju akan membayar kompensasi carbon offset kepada negara berkembang atas hutan yang dimiliki yang berfungsi dalam penurunan emisi GRK.

Serangkaian kegiatan yang perlu dilakukan untuk implementasi REDDdapat dikelompokan dalam 4 komponen (IFCA, 2007), yaitu: komponen I - Penyiapan Infrastruktur, meliputi penetapan tingkat emisi acuan/ reference emission level (REL), penyusunan strategi penurunan deforestasi dan degradasi hutan, penyusunan metodologi monitoring emisi dan sequestrasi karbon, penetapan mekanisme pasar/sistem penjualan karbon, dan pengaturan distribusi pendapatan dari penjualan karbon; komponen 2 - Identifikasi aktivitas untuk pengurangan emisi karbon; komponen 3 Pengembangan sistem pasar, dan komponen 4 Penegakan hukum oleh pemerintah.

Konsep REDD tersebut telah dibahas dan dinegosiasikan dalam berbagai forum global/ internasional diantaranya Conference on Parties (COP) 13/2007 di Bali-Indonesia, COP 14/2008 di Poznan-Polandia, COP 15/2009 di Copenhagen-Swedia, COP 16/2010 di CancunMexico, COP I7/20II di Durban-Afrika Selatan, dan COP 18/2012 (26 November - 8 Desember 2012) di Doha-Qatar. Skema REDD diharapkan dapat menggantikan skema CDM (Clean Development Mechanism) yang berakhir tahun 2012 sesuai komitmen yang ada dalam Kyoto Protocol. Namun dengan belum adanya kesepakatan implementasi REDD+ maka pada COP 17/20II di Durban, disepakati Kyoto Protocol diperpanjang sampai tahun 2020.

Proses penyusunan skema REDD yang dibahas melalui COP setiap tahun berjalan sangat lambat karena beberapa hal. Pertama, hak dan kewajiban antara negara maju (Annex I Countries) dan negara berkembang (NonAnnex I Countries) belum jelas, masih dalam proses diskusi dan negosiasi pada berbagai forum pertemuan global. Kedua, ada yang berpendapat bahwa pemerintah merupakan penyebab utama (primary driver) kerusakan hutan karena pemerintah sebagai penguasa/pemilik hutan tidak jarang membuat kebijakan yang mengakibatkan kerusakan hutan itu sendiri (misalnya penerbitan izin pembukaan hutan untuk pembalakan, perkebunan, pertambangan, pemukiman dII). Ketiga, belum jelasnya hak kepemilikan (property right) atas lahan/hutan terutama di pedesaan, dan keterlibatan masyarakat lokal. Pengembangan ekonomi lokal, kejelasan hak atas lahan/ hutan dan pengelolaan hutan yang melibatkan masyarakat setempat dapat meningkatkan tutupan hutan sebagaimana yang terjadi di Korea Selatan, China, Vietnam dan Nepal. Keempat, korupsi yang banyak terjadi di negara berkembang (misalnya kasus suap, manipulasi dokumen, sistem accounting yang manipulatif, penggelapan pajak dIl.) meragukan para pemilik modal untuk mendanai skema REDD karena kekhawatiran kebocoran dana dan penggunaan yang tidak sebagaimana mestinya. Kelima, laporan penelitian baru-baru ini menunjukan bahwa deforestasi hanya menyumbang $8 \%$ dari emisi yang terjadi, bukan $20 \%$ sebagaimana yang didengungkan selama ini (White, 20I I). Namun demikian, skema REDD tetap diperlukan dalam rangka penurunan emisi GRK, meskipun kompensasinya tidak sebesar yang diharapkan selama ini. Keenam, skema REDD menjadi kurang menarik karena insentif/kompensasi yang akan diperoleh tidak cukup besar (jika dibandingkan dengan penerimaan kompensasi dari perkebunan atau pertambangan). Dilain pihak, investasi yang diperlukan untuk persiapan dan pembangunan infrastruktur dalam rangka implementasi REDD (4 komponen tsb di atas) sangat besar dan memerlukan proses yang kompleks.

Perlu kajian dari aspek hukum islam Kajian dari sisi hukum islam atas insentif/kompensasi emisi karbon dengan skema REDD dimaksudkan sebagai bahan diskusi lebih lanjut dan untuk mendapat tanggapan dari para pembaca khususnya para pemuka agama islam dan ahli hukum islam. Sebagaimana disebutkan sebelumnya bahwa pengukuran emisi GRK memerlukan proses cukup rumit. Dalam hal emisi GRK dari hutan (biasa disebut karbon hutan), pengukuran dilakukan pada 5 (lima) sumber karbon (carbon pools), yaitu: (i) biomassa (semua bagian pohon/vegetasi) di atas permukaan tanah, (ii) biomassa di bawah permukaan tanah (akar), (iii) kayu mati, (iv) seresah, dan (v) bahan organik tanah. 
Pengukuran emisi karbon hutan semakin kompleks apabila melibatkan lahan gambut yang disinyalir menyimpan karbon hutan sangat tinggi, tetapi juga dapat mengeluarkan emisi GRK yang tinggi pula bila terkena gangguan (kebakaran, pembalakan). Metode pengukuran dan penghitungan emisi karbon hutan diuraikan dan dijelaskan dalam berbagai referensi diantaranyadalam Pedoman dari Intergovernmental Panel on Climate Change (IPCC Guideline) Tahun 2000, IPCC Guideline Tahun 2003 (LULCF), dan IPCC GuidelineTahun 2006 (AFOLU). Meskipun demikian, prosedur pengukuran karbon hutan yang disepakati para pihak, dan yang mudah diimplementasikan di lapangan belum tersedia sehingga hasil pengukuran karbon hutan pada suatu lokasi tertentu bisa berbeda diantara para pihak yang melakukan pengukuran pada lokasi tersebut.

Pengukuran karbon hutan untuk biomassa dilakukan dengan menggunakan persamaan alometri yang diperoleh dari analisis regresi untuk satu jenis atau kelompok jenis pohon. Sebagai contoh persamaan alometri untuk mengukur biomassa di atas muka tanah (carbon pool nomor I) untuk pohon pinus $=0,0417 \mathrm{D}$ 2,6576 (Waterloo, 1995 dalam Hairiah dan Rahayu, 2007), sedangkan biomassa di atas muka tanah untuk pohon hutan alam di lahan basah = 0,037D I,89H (Brown, 1997). Keterangan: $D=$ diameter pohon setinggi dada; $\mathrm{H}=$ tinggi pohon.

Sebagaimana dalam perdagangan barang pada umumnya maka dalam konpensasi karbon dengan skema REDD berlaku pula prinsipprinsip jual beli yang perlu sejalan dengan aturan/hukum dalam islam. Dari pandangan islam meskipun terdapat beda pendapat diantara mazhab yang ada, pada dasarnya rukun jual beli meliputi: adanya penjual dan pembeli, adanya barang yang akan dijual, dilakukannya ijab kabul, dan dilakukannya pembayaran (Dahlan, 2006). Sedang syarat barang yang dijual-belikan adalah adanya kejelasan baik hitungan, timbangan, takaran, maupun kualitasnya. $\mathrm{Hal}$ ini dimaksudkan untuk menghindari adanya gharar (penipuan, ketidakpastian, ketidakjelasan) dan supaya ada saling kepercayaan pada masingmasing pihak penjual dan pembeli. "Abu Hurairah mengatakan bahwa Rasulullah SAW melarang jual beli hashah dan jual beli gharar" (HR Bukhari, Muslim, Malik, Ahmad, Tirmidzi, an-Nasa i, Abu Dawud, Ibnu Majah)."

Karbon hutan yang sebagai komoditas kompensasi (carbon offset), barangnya tidak terlihat secara nyata/tidak kasat mata; kandungan karbon hutan diketahui/diukur dari 5 sumber (carbon pools) dengan menggunakan persamaan matematik/statistik, dan nilai yang disepakati bersama (default value) sebagaimana disebutkan pada uraian di atas. Akurasi dari pengukuran/ perhitungan tersebut belum diketahui secara jelas.

Firman Allah SWT dalam surat AI Mutaffifin (I-3) mengatakan: "Kecelakaan besarlah bagi orang-orang yang curang, yaitu orang-orang yang dalam menimbang untuk dirinya minta dipenuhi takarannya tetapi dalam menimbang untuk orang lain dikurangi takarannya (Q.S. 83: I-3)". Selanjutnya, firman Allah SWT dalam surat Al-Isra (35) menyebutkan: "Dan sempurnakanlah takaran apabila kamu menakar, dan timbanglah dengan neraca yang benar. Itulah yang lebih utama (bagimu) dan lebih baik akibatnya (Q.S. 17: 35)". Tentunya masih banyak aturan dan ketentuan yang ada dalam Al-Qur'an dan Hadist tentang perdagangan dan jual beli, dan untuk kajian lebih mendalam terkait perdagangan karbon ini kiranya perlu pembahasan lebih lanjut oleh pihak yang lebih memahami hukum jual beli dan perdagangan dalam islam untuk mendukung implementasi perdagangan/kompensasi karbon dengan skema REDD yang merupakan agenda penting pemerintah dalam pembangunan nasional saat ini.

\section{KESIMPULAN DAN SARAN}

Berdasar hasil penelitian dan pembahasan, maka dapat diambil kesimpulan sebagai berikut:

I. Iklim bumi telah berubah cepat disebabkan oleh kenaikan gas rumah kaca (GRK) di udara sebagai akibat kegiatan manusia terutama kegiatan dalam penggunaan energi fosil, dan penggunaan lahan untuk pertanian, perkebunan, pertambangan, pemukiman dan industri.

2. Temperatur di bumi akan terus meningkat jika emisi GRK tidak berkurang. Kenaikan 
temperatur akan mempunyai akibat serius terhadap kehidupan di muka bumi karena kenaikan temperatur akan menyebabkan terjadinya bencana banjir, kekurangan pangan, kematian, dan punahnya beberapa species flora dan fauna.

3. Emisi GRK dapat diturunkan dengan cara mengurangi permintaan barang \& jasa yang proses produksinya berakibat terjadinya emisi secara intensif; berpindah ke teknologi rendah emisi GRK, dan menghindari kegiatan yang mengakibatkan emisi dari alih fungsi lahan.

4. Konsep pemberian insentif/kompensasi atas penurunan emisi GRK dengan skema REDD (Reducing Emission from Deforestation and forest Degradation) didasari oleh pendapat bahwa biaya penurunan emisi GRK dengan menghindari deforestasi adalah lebih murah dari pada biaya penurunan emisi di sektor lain. Namun sampai saat ini REDD belum dapat diimplementasikan karena adanya beberap permasalahan diantaranya tarik menarik kepentingan antara negara maju dan negara berkembang, dan masih adanya keraguan pemilikmodal untuk berinvestasi di bidang ini karena masih adanya penyalahgunaan jabatan/ kewenangan (penyuapan, korupsi) di pemerintahan terutama di negara berkembang.

5. Beberapa hal perlu menjadi perhatian untuk terselenggaranya perdagangan karbon dengan skema REDD. Pembangunan infrastruktur untuk implementasi REDD utamanya dalam pengukuran (measurement), pelaporan (Reporting) dan verifikasi (Verification) perlu segera diselesaikan dan dibahas dalam forum internasional agar REDD dapat dilaksanakan secara operasional. Disamping itu, kebijakan dan aturan yang mendukung keterlibatan masyarakat lokal perlu disiapkan untuk menciptakan lapangan kerja bagi masyarakat sekitar hutan.
6. Pengukuran dan penghitungan karbon hutan sbg komoditas yg dijual belikan dalam perdagangan/kompensasi karbon dengan skema REDD perlu dilakukan dengan prosedur yang jelas agar jelas pula kualitas, ukuran, timbangan dan takaran dari barang dimaksud, sehingga secara hukum islam perdagangan ini benar dan sah.

\section{DAFTAR PUSTAKA}

Brown, S. (1997). Estimating biomass and biomass change of tropical forests. $A$ primer UN FAO Paper 134.

Climate Change Secretariate of Srilangka. (2012). Carbon Market. Diakses tanggal 30 Mei 2013 dari: www.climatechange. Ik/DNA/carbon_market.html

Dahlan, Abdul Azis. (2006). Ensiklopedi Hukum Islam. Jakarta. PT Ichtiar Baru van Hoeve.

Hairiah, K dan Rahayu, S. (2007). Pengukuran Karbon Tersimpan diberbagai macam penggunaan lahan. Bogor. ICRAF.

IFCA. (2007). Consolidation Report: $\begin{array}{lcr}\text { Reducing } & \begin{array}{c}\text { Emissions } \\ \text { Deforestation }\end{array} \text { and } & \text { from } \\ \text { Forest }\end{array}$ Degradation in Indonesia. Jakarta. Ministry of Forestry - Indonesia.

Satgas REDD+. (20/2). Tanya jawab Tentang

REDD+. Diakses tanggal 30 Mei 2013

dari: www.satgasreddplus.org/tentangredd.

Stern, N. (2006). Stern Review: The Economic of Climate Change. Cambridge. Cambridge University Press.

White, Andy. (20II). Cash alone will not slow forest carbon emissions. Nature 47I. Washington, DC.

Wilkinson, Nick. 2005. Managerial Economics: A problem-solving approach. Cambridge University Press. New York.

World Resources Institute (WRI). (2006). Climate Analysis Indicators Tool (CAIT) on-line database version 3.0., Washington, DC. World Resources Institute. Diakses tanggal 30 Mei 2013 dari: http://cait.wri.org. 